\title{
Penerapan Metode Gantt Chart dalam Menentukan Penjadwalan Kinerja Karyawan
}

\author{
Meilin Widyastuti' ${ }^{1}$, Eka Irawan ${ }^{2}$, Agus Perdana Windarto ${ }^{3}$ \\ Mahasiswa Program Studi Sistem Informasi ,STIKOM TUNAS BANGSA PEMATANGSIANTAR \\ Jl.Jenderal Sudirman Blok A No.1/2/3 Pematangsiantar,Medan,Indonesia,21127 \\ Email : meilin20widyastuti@gmail.com¹),_kairawan@amiktunasbangsa.ac.id²), \\ agusperdana@amiktunasbangsa.ac.id ${ }^{3}$
}

\begin{abstract}
Performance has a very important role because performance is the form of the end result of the employee process completing their tasks. Employees who complete their tasks properly and correctly will have high performance. A leader or head of an organization will be recognized as a leader if he can direct his subordinates towards achieving organizational goals. Effective leadership is certainly needed in promoting employee performance, but needs to be supported by a good work environment. The existence of leadership and a good work environment is expected to improve employee performance. This study aims to determine the function of delay in completing the task. It requires analysis and the right approach to analyzing employee performance so that it can optimize the use of work time that is efficient in human resources. used is the Gantt Chart method which is used to show the tasks on the project as well as the schedule and time of implementation, such as the time of commencement of the task and also the time imit used to complete the task in question. tasks and allocation of employees better.
\end{abstract}

Keywords: Employees, Gantt Chart.

Abstrak - Kinerja memiliki peranan yang sangat penting karena kinerja merupakan bentuk hasil akhir dari proses karyawan menyelesaikan tugasnya.Karyawan yang menyelesaikan tugasnya dengan baik dan benar maka akan memiliki kinerja yang tinggi. Seorang pemimpin atau kepala suatu bagian organisasi akan diakui sebagai seorang pemimpin jika dapat mengarahkan bawahannya kearah pencapaian tujuan organisasi. Kepemimpinan yang efektif tentunya sangat dibutuhkan dalam mendorong peningkatan kinerja karyawan, namun perlu didukung dengan lingkungan kerja yang baik. Adanya kepemimpinan dan lingkungan kerja yang baik diharapkan kinerja karyawan dapat meningkat.Penelitian ini bertujuan untuk mengetahui fungsi keterlambatan dalam menyelesaikan tugasnya.untuk itu diperlukan analisis dan pendekatan yang tepat untuk menganalisis kinerja karyawan sehingga dapat mengoptimalkan pemakain waktu kerja yang efisiensi sumber daya manusia.metode yang digunakan adalah metode Gantt Chart yang digunakan untuk menunjukan tugas-tugas pada proyek serta jadwal dan waktu pelaksanaannya, seperti waktu dimulainya tugas tersebut dan juga batas waktu yang digunakan untuk menyelesaikan tugas yang bersangkutan.Berdasarkan pada hasil penelitian kinerja karyawan ini dapat diharapkan perusahaan dapat melakukan pembagian tugas dan pengalokasian karyawan dengan lebih baik.

Kata kunci : Karyawan, Gantt Chart.

\section{PENDAHULUAN}

Penjadwalan dibutuhkan untuk mengurangi efisiensi tenaga operator, mesin dan peralatan produksi, dan dari aspek lainnya untuk lebih efisien[1]. Hal ini sangat penting dalam pengambilan keputusan dalam proses kelangsungan 
produksi. Ada beberapa faktor seseorang tersebut berhasil menyelesaikan pekerjaan diantaranya faktor shift kerja. Berdasarkan pengamatan penulis ada beberapa kendala yang terjadi di bagian, Department housekeeping, Kitchen dan Reception[2]. Masalah penjadwalan pada pekerja housekeeping hotel memiliki operasional hotel selama 16 jam dalam 1 hari sehingga penjadwalan pekerja lebih dari satu alokasi. Penjadwalan peraturan shift kerja pada pekerja housekeeping disebabkan adanya karyawan yang baru saja keluar sehingga housekeeping mengalami perubahan penjadwalan yang tidak adanya pengganti jadwal perminggu. Batasan pekerja juga menjadi salah satu pertimbangan dalam penjadwalan pekerja shift, Sehingga jadwal haousekeeping ditentukan dan disepakati antar anggota housekeeping, kendala lain dapat di perlihatkan dalam penjadwalan pekerja shift bagian Kitchen merupakan penjadwalan shift kerja yang tidak berjalan dengan baik dikarenakan kekurangan anggota dan jadwal peraturan kerja telah disepakati oleh karyawan department. Salah satu kendala tambahan yang terjadi di penjadwalan bagian Reception yang juga menggalami kendala pada penjadwalan karyawan adanya karyawan yang kuliah sehingga mengakibatkan penjadwalan yang dilakukan menggunakan rolling kerja perminggu.

\section{METODOLOGI PENELITIAN}

Salah satu komponen yang penting dalam penelitian adalah proses pengumpulan data. Teknik pengumpulan data merupakan langkah yang paling strategis dalam penelitian, karena tujuan utama dari penelitian adalah mendapatkan data. Pengumpulan data yang digunakan untuk penelitian terdapat beberapa metode yang terdiri dari :

a. Penelitian Kepustakaan (Libarry Research) yaitu memanfaatkan perpustakaan, buku, prosiding atau jurnal sebagai media untuk bahan referensi dalam menentukan faktor, parameter dan label yang digunakan untuk penelitian.

b. Penelitian Lapangan (Field Work Research) yaitu penelitian yang dikukan secara langsung dilapangan dengan mengunakan beberapa teknik seperti berikut :

1. Wawancara adalah proses pengumpuilan data atau informasi melalui tatap muka antara pihak penanya (Interviewer) dengan pihak yang ditanya atau penjawab (interviewer). Hal ini penulis lakukan dengan melakukan tanya jawab dengan staf teknik sesuai kasus yang diangkat penulis .

2. Dokumentasi adalah pengumpulan data yang dilakukan untuk mendapatkan data sukunder dari dokumen - dokumen atau arsip- arsip yang relavan dengan penelitian ini. Hal ini penulis lakukan dengan membuat dokumen penilain sampel alternatif terhadap sesi wawancara yang telah didiskusikan.

\subsection{Analisis Data}

Metode analisis data terdiri atas dua macam, yaitu metode statistik deskriptif dan metode statistik inferensial. Pada metode penelitian penulis menggunakan metode penelitian kuantitatif yang termasuk dalam metode statistik inferensial. Statistik inferensial adalah statistik yang berkaitan dengan analisis data (sampel), kemudian diambil kesimpulan yang digeneralisasikan kepada seluruh populasi dan digunakan untuk menarik inferensi dari sampel ke popula. Analisis statistik inferensial dapat dikatakan sebagai metode analisis dengan menggunakan data 
yang berbentuk angka dan di analisis dengan cara membandingkan melalui perhitungan dan mengaplikasikannya dengan cara menggunakan rumus yang sesuai. Analisis statistik inferensial digunakan untuk menguji parameter populasi data yang ada, dengan menggunakan data yang berasal dari responden.

\subsection{Penjadwalan}

Penjadwalan adalah aktivitas perencanaan untuk menentukan kapan dan dimana setiap operasi sebagai bagian dari pekerjaan secara keseluruhan harus dilakukan pada sumber daya yang terbatas, serta pengalokasian sumber daya pada suatu waktu tertentu dengan memperhatikan kapasitas sumber daya yang ada. Penjadwalan dapat diartikan sebagai pengalokasian sejumlah sumber daya (resource) untuk melakukan sejumlah tugas atau operasi dalam jangka waktu tertentu dan merupakan proses pengambilan keputusan yang peranannya sangat penting dalam industri manufaktur dan jasa yaitu mengalokasikan sumber-sumber daya yang ada agar tujuan dan sasaran perusahaan lebih optimal[3].

\subsection{Pert Chart}

PERT merupakan suatu metode yang bertujuan sebanyak mungkin mengurangi adanya penundaan, maupun gangguan dan konflik produksi, mengkoordinasikan dan mensinkronisasikan berbagai bagian sebagai suatu keseluruhan pekerjaan, dan mempercepat selesainya proyek[4].

\subsection{Gantt Chart}

Gantt Chart merupakan diagram perencanaan yang digunakan untuk penjadwalan sumber daya dan alokasi waktu. Gantt Chart adalah contoh teknik non-matematis yang banyak digunakan dan sangat popular di kalangan para manajer karena sederhana dan mudah dibaca. Gantt Chart dapat membantu penggunanya untuk memastikan bahwa, Semua kegiatan telah direncanakan, urutan kinerja telah diperhitungkan Perkiraan waktu kegiatan telah tercatat, keseluruhan waktu proyek telah dibuat. Gantt Chart sangat mudah dipahami, balok horizontal (horizontal bar) dibuat pada tiap kegiatan proyek sepanjang garis waktu. Gantt Chart juga dapat digunakan untuk penjadwalan operasi yang berulang. Gantt chart digunakan untuk penjadwalan sederhana atau proyekproyek yang kegiatannya tidak terlalu berkaitan atau proyek kecil, sedangkan network untuk penjadwalan proyek yang rumit[5].

\section{HASIL DAN PEMBAHASAN}

Hasil dan pembahasan pada bab ini disajikan sesuai penelitian yang dilakukan. Data yang digunakan dalam penelitian ini di dapat dari grand plam hotel pematangsiantar. Data set yang ada terdiri dari beberapa tabel penjadwalan kinerja karyawan yang ada di pembahasan sebelumya yaitu bab 3. Kumpulan data yang diperoleh digunakan sebagai data masukan dalam membuat suatu model yaitu algoritma pert chart dan gantt chart, yang akan di hitung mengunakan pert chat. Pert chart sendiri berfungsi untuk menghitung waktu berapa lama dalam membuat suatu proses penjadwalan,sedangkan gantt chart untuk membuat jadwal pekerja hotel lebih terstuktur. 


\subsection{Perhitungan Pert Chart}

Langkah-langkah pengolahan data untuk menentukan penjadwalan yang akan dilakukan di perhitungan pert chart dan gantt chart sebagai berikut :

1) Perhitungan pert chart dapat dilihat dengan langkah-langkah sebagai berikut:

a) Menentukan waktu untuk tiga angka estimasi yang digunakan dalam perhitungan maju dan mundur. Rumus-rumus yang digunakan antara lain:

$$
\begin{aligned}
& \operatorname{Mean}_{(t e)}=\frac{\left(a+4_{m}+b\right)}{6} \\
& \text { Standart Deverasi }(\sigma \mathrm{te})=\frac{(\mathrm{b}-\mathrm{a})}{6} \\
& \text { Variasi }\left(\sigma \mathrm{te}^{2}\right)=\left\{\frac{(\mathrm{b}-\mathrm{a})}{6}\right\}^{2}
\end{aligned}
$$

b) Membuat perhitungan untuk keseluruhan aktivitas, serta mengidentifikasi jalur kritis dan lamanya proyek konstruksi dapat diselesaikan dengan rumus Perhitungan maju :

$\mathrm{ES}(\mathrm{j})=\operatorname{Maks}\{\mathrm{EF}(\mathrm{i})$ dari seluluh kegiatan terdahulu $\}$

$E F(i-j)=E S(i-j)+d(i-j)$

Perhitungan mundur :

$\mathrm{LF}(\mathrm{j}) \quad=\operatorname{Min}\{\mathrm{LS}(\mathrm{i})$ dari seluluh kegiatan terdahulu $\}$

$$
L S(i-j)=L F(i-j)-d(i-j)
$$

Berikut adalah data uraian pekerjaan yang sudah di olah menjadi data kegiatan:

Tabel 1. Uraian Kegiatan

\begin{tabular}{|l|l|l|}
\hline Bagian & ID & \\
\hline \multirow{5}{*}{ Kause } & A & Mengkordinir bidang kerja bagian seleksi house keeping \\
\cline { 2 - 3 } & B & Membuat perencanaan tentang house keeping \\
\cline { 2 - 3 } & C & Lobi Mengadakan Evauasi Kerja \\
\cline { 2 - 3 } & D & Menyediakan alat - alat yang di gunakan house keeping \\
\hline & E & Merencanakan dan membuat penambahan data set \\
\hline & F & Mengadakan instuksi pada setiap anggota house keeping \\
\cline { 2 - 3 } & G & Mengontrol semua bagian house keeping \\
\cline { 2 - 3 } & H & Memberikan masukan pada anggota hause keeping \\
\hline \multirow{5}{*}{ Kitchen } & A & Chief cook \\
\cline { 2 - 3 } & B & Assistand chef/ sous chef \\
\cline { 2 - 3 } & C & Mengawasi jalanya operasional \\
\cline { 2 - 3 } & D & Memberikan tugas pada anggota \\
\cline { 2 - 3 } & E & Memberikan wejangan pada angota \\
\hline \multirow{5}{*}{ Reception } & A & Memastika layanan pelangan tepat waktu dan akurat \\
\cline { 2 - 3 } & B & Menangani keluhan dan permintaan pelangan \\
\cline { 2 - 3 } & C & Memecahkan masalah darurat \\
\cline { 2 - 3 } & D & Memantau persediaan stok perlengkapan kantor \\
\cline { 2 - 3 } & E & Memastikan distribusi surat yang benar \\
\cline { 2 - 3 } & F & Menyediakan catattan biaya dan biaya kantor yang sudah di perbaiki \\
\cline { 2 - 3 } & G & Memastikan kebijakan dan keamanan perusahaan terpenuhi \\
\hline & & \\
\hline
\end{tabular}

\subsection{Tampilan Jadwal Hotel}

Adapun tampilan jadwal yang telah di buat adalah :

a. Tampilan Diklat 
Tampilan ini muncul ketika pihak hotel telah membuat suatu kegiatan yang mana kegiatan tersebut telah di susun secara teratur oleh pihak hotel. Tampilanya dapat dilihat pada gambar 1 .

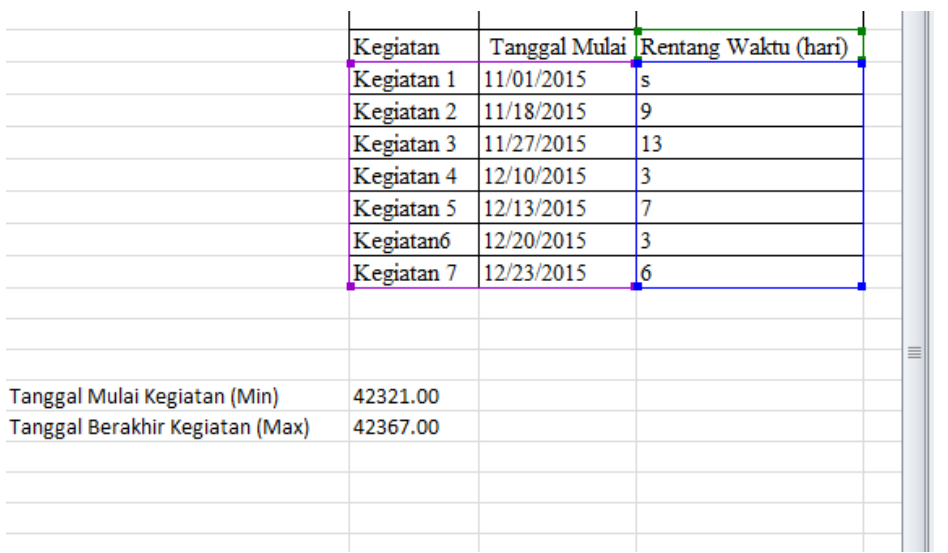

Gambar 1. Tampilan Diklat

b. Tampilan Jadwal Rentang Waktu

Tampilan ini menampilkan hasil dari tampilan diklat hotel yang mana hasil tersebut di hasilkan dari kegiatan ,jadwal serta rentang waktu. Memasukan semua kegiatan dengan cara mengselect data satu persatu . hasil dari select tersebut menghasilkan kegiatan waktu yang telah di atur di dalam bar chart.

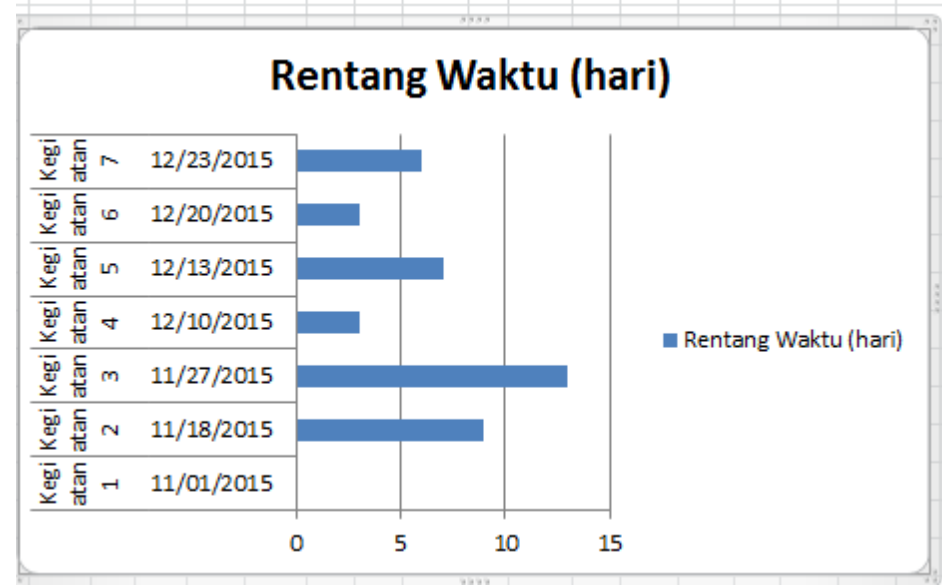

Gambar 2. jadwal Rentang Waktu

c. Tampilan Kinerja Pegawai Hotel

Adapun kinerja hotel di grand plam terbagi 3:

1. Kichen

Kinerja hotel khususnya kichen sudah di susun secara teratur di karenakan jadwal pegawainya yang kuliah sehinggah pada jadwal yang sebelumnya tidak di camtumkan apakah kinerja nya disesuaikan sesuai jadwal kuliah. Dan sekarang sudah di susun bedasarkan data yang ada di mana jika pegawai kuliah maka hasil harinya akan di kurang satu sehingga renggang nya dapat teratasi, dapat dilihat pada gambar 3.3

Menentukan Penjadwalan Kinerja Karyawan dengan metodeGent Chart (Meilin Widyastuti) | 561 
KITCHEN

SCHEDULE OF OKTOBER 2018

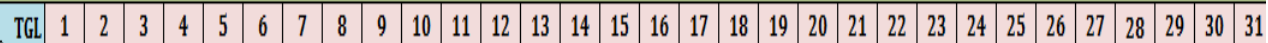

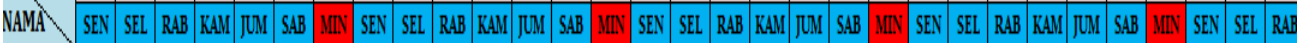

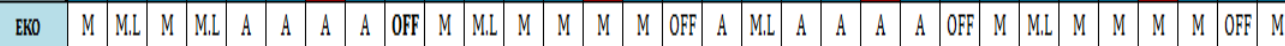

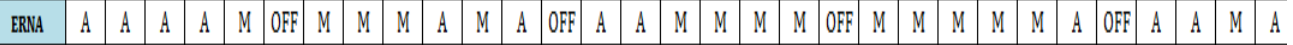

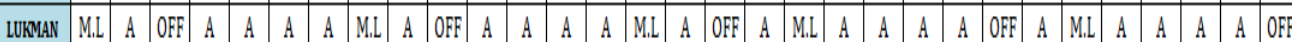

Gambar 3. Tampilan Kinerja Kitchen

\section{Reception}

Tampilan di atas di susun hampir sama dengan kichen karena hampir semua pegawainya kuliah pada jam yang berbeda-beda dan caranya penggunanaya sama ketika ada pegawai yang kuliah maka akan di kurangin satu dengan hari yang sebelumnya. Dapat dilihat pada gambar 4.

\begin{tabular}{|c|c|c|c|c|c|c|c|c|c|c|c|c|c|c|c|c|c|c|c|c|c|c|c|c|c|c|c|c|c|c|c|}
\hline \multicolumn{32}{|c|}{ Reception } \\
\hline \multicolumn{32}{|c|}{ SCHEDULE OF OKTOBER 2018} \\
\hline TGL & 1 & 2 & 3 & 4 & 5 & 6 & 7 & 8 & 9 & 10 & 11 & 12 & 13 & 14. & 15 & & 17 & 18 & 19 & 20 & 212 & 22 & 23 & 24 & 25 & 262 & 272 & 2829 & 2930 & 303 & 31 \\
\hline $\mathrm{AMA} \backslash$ & & SEL & RAB & KAM & JUI & $S A B$ & MIN & SEN & SEl & RAB & KAM & $\pi \mathrm{M}$ & $S A B$ & MIN $/ s$ & $\mathrm{EN} / \mathrm{S}$ & 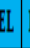 & RAB & KAM & תות & $S A B$ & IIN SI & SEN & SEL & $R A B$ & KAM & $\pi \mathrm{S} / \mathrm{s}$ & $\triangle A B$ & & EN $\mid$ SE & $\begin{array}{lll}E L & R A\end{array}$ & $2 A B$ \\
\hline ANA & $A$ & $A$ & $A$ & $M$ & $M$ & M & OFF & M & $M$ & $A$ & M & $A$ & A & OFF & A & n & $A$ & M & $A$ & A & OFF & $A$ & $A$ & $A$ & $M$ & $M$ & $\begin{array}{lll}M & 0\end{array}$ & OFF $M$ & $M M$ & $\mathrm{~N} N$ & M \\
\hline HABBB & M & $\mathrm{M}$ & M & $\mathrm{M}$ & M & A & OFF & $A$ & A & M & $A$ & M & A & OFF & A & y & M & M & M & A & OFF & A & A & $M$ & M & M & $\begin{array}{lll}A & 0\end{array}$ & OFP A & $\begin{array}{ll}A & A\end{array}$ & $A$ A & A \\
\hline BAYU & $A$ & $A$ & M & $A$ & $A$ & $A$ & OFF & $A$ & A & M & M & $M$ & M & OFF & M & M & M & $A$ & $\mathrm{M}$ & $M$ & OFF 1 & M & M & $M$ & A & $A$ & $\begin{array}{lll}A & 0\end{array}$ & OFF A & $\begin{array}{lll}A & A\end{array}$ & $A \quad M$ & M \\
\hline
\end{tabular}

Gambar 4. Tampilan Receptionis

\section{House Keeping}

Hause Keeping sama hal nya dengan dengan kichen dan receptionis hanya saja yang membedakan tidak ada pegawai yang kuliah dan jam kerja nya melebihi jam kerja dari 16 jam perhari. Dapat dilihat pada gambar 5 .

\begin{tabular}{|c|c|c|c|c|c|c|c|c|c|c|c|c|c|c|c|c|c|c|c|c|c|c|c|c|c|c|c|c|c|c|c|}
\hline \multicolumn{32}{|c|}{ SCHEDULE OF OKTOBER 2018} \\
\hline & & 2 & 3 & 4 & 5 & 6 & 7 & 8 & 9 & 10 & 11 & 12 & 3 & 14 & 15 & 16 & 17 & 18 & 19 & 20 & 21 & 22 & 23 & 24 & 25 & 26 & 27 & & 29 & & 31 \\
\hline 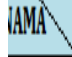 & II & SEl & RAB & $\mathrm{KAM}$ & $\pi \mathbb{M}$ & $S A B$ & $\mathbb{I N}$ & SES & SEL & RAB & $\mathrm{KAM}$ & ת & $S A B$ & IIIN & SEN & SEL & RAB & $\mathrm{KAl}$ & תוב & $S A B$ & IIIX] & SEN & SEL & RAB & $\mathrm{KAM}$ & 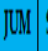 & $S A B$ & & SEN & SEL & $R A B$ \\
\hline ANDRE & M & M & MLL & M & M & M.L & $M$ & M & M.L & $M$ & $A$ & $A$ & M.L & M & M & M & M.L & M & M & MLL & M & M & M & $A$ & $A$ & A & $A$ & $A$ & $A$ & M & M \\
\hline All & M & M & M & $M$ & $A$ & M & M & M & M & $M$ & M & M & M & M & M & M & M & M & $A$ & A & A & A & A & M & M & M & $M$ & M & $\mathrm{M}$ & A & A \\
\hline IRUL & $A$ & A & $A$ & $A$ & M & $A$ & $A$ & $A$ & $A$ & $A$ & M & $M$ & $A$ & $A$ & $A$ & $A$ & $A$ & $A$ & M & $M$ & $\mathrm{M}$ & $M$ & & & & & & & & & \\
\hline
\end{tabular}

Gambar 5. Tampilan House Keeping

Menjelaskan keterkaitan hasil berdasarkan metodologi dan kebenaran representasi dan landasan teori yang memperoleh solusi dan pemecahan masalah. Yang menjelaskan bagaimana masukan didalam pembuatan rancangan penjadwalan pegawai grand plam hotel. Hasil yang di dapat adalah jadwal diklat 
yang akan di gunakan pegawai untuk melihat jadwal yang sudah di tetapkan .Adapun jadwal yang di gunakan adalah :

a. Kegiatan

Kegiatan di gunakan adalah jadwal yang akan di langsungkan secara berurut oleh pihak hotel,yang mana kegiatan tersebut di rancang sesuai kegiatan yang berlangsung.

b. Tanggal Kegiatan

Tanggal kegiatan yang dimaksud adalah seberapa banyak jadwal yang digunakan untuk membuat suatu jadwa dari kegiatan.

c. Rentang Waktu

Rentang waktu yang di gunakan beberapa jadwal yang digunakan seperti batasbatas waktu yang akan berakhir.

\section{KESIMPULAN}

Berdasarkan pembahasan sebelumnya dapat disimpulkan bahwa:

1. Hasil penelitian yang diperoleh dapat disimpulkan bahwa perhitungan gantt chart dan pert chart dapat digunakan untuk menyelesaikan sebuah penjadwalan kinerja di Grand Plam Hotel Pematangsiantar. Pert chat dapat di kombinasikan dengan gantt chat untuk menghitung suatu penjadwalan yang objektif. Hasil dari perhitungan pert chat dapat menghasilkan perkiraan berapa lama proyek tersebut.

2. Hasil yang diperoleh dari metode gantt chart yang di implemntasikan ke dalam software microsoft excel sesuai dengan jadwal yang ada dan menghasilkan nilai rentang waktu berkisar 5,10 dan 15. Dan disimpulkan bahwa metode gantt chart adalah sebuah metode yang mudah untuk mengatur sebuah penjadwalan.

\section{DAFTAR PUSTAKA}

[1] M. Marbun and B. Sinaga, "Buku Ajar Sistem Pendukung Keputusan Penilaian Hasil Belajar STMIK Pelita Nusantara Medan Buku Ajar," 2018.

[2] W. Yuliyanti and Santoso, "Perencanaan Dan Pembuatan Aplikasi Absensi Dosen Menggunakan Radio Frequency Identification ( RFID ) ( Studi Kasus Politeknik Negeri Tanah Laut )," Semin. Nas. Inov. DAN Apl. Teknol. DI Ind., 2016.

[3] D. M. Walean, "PERENCANAAN DAN PENGENDALIAN JADWAL DENGAN MENGGUNAKAN PROGRAM MICROSOFT PROJECT 2010 ( Studi Kasus : Proyek PT . Trakindo Utama ),” J. Sipil Statik, vol. 1, no. 1, 2012.

[4] R. Maharesi, "Penjadwalan Proyek Dengan Menggabungkan Metode PERT Dan CPM," 2009.

[5] A. T. HIDAYAT, "ANALISIS PENGARUH SHIFT KERJA TERHADAP BEBAN KERJA PADA PEKERJA DI PT . PRIMARINDO ASIA FAKULTAS TEKNIK UNIVERSITAS ISLAM BANDUNG 2011 M / 1432 H ANALISIS PENGARUH SHIFT KERJA TERHADAP BEBAN KERJA PADA PEKERJA DI PT . PRIMARINDO ASIA," 2011. 